\title{
The Key Reasons for Cross - Listing in East African Stock Exchanges by Firms Listed in the Nairobi Securities Exchange
}

\author{
Kennedy Munyua Waweru ${ }^{1}$, Ganesh P. Pokhariyal ${ }^{2} \&$ Muroki F. Mwaura ${ }^{3}$ \\ ${ }^{1}$ Department of Accounting and Finance, Mount Kenya University, Thika, Kenya \\ ${ }^{2}$ School of Mathematics, University of Nairobi, Nairobi, Kenya \\ ${ }^{3}$ Department of Accounting and Law, William Paterson University, New Jersey, USA \\ Correspondence: Kennedy Munyua Waweru, Department of Accounting and Finance, Mount Kenya University, \\ P.O. Box 342, Thika, Kenya. Tel: 254-721-344-475. E-mail: kenwawerum@gmail.com
}

Received: April 30, 2012 Accepted: June 13, 2012 Online Published: August 16, 2012

doi:10.5539/ijbm.v7n16p118 URL: http://dx.doi.org/10.5539/ijbm.v7n16p118

\begin{abstract}
The purpose of this study was to investigate the key reasons behind the decision by the firm management of Nairobi Securities Exchange (NSE) listed firms to cross-list in East African Exchanges. The study employed a descriptive research design. A Likert type questionnaire was administered to the Chief Executive Officers (CEOs) or the Chief Financial Officers (CFOs) of the target firms. The study conducted factor analysis to identify the key reasons for the cross-listing in the East African region. The key reasons identified were investor recognition, expansion of business, boosting of sales and desire to lower the cost of capital. The factor analysis did not provide evidence that legal bonding is a motivation for the cross-listing by NSE firms. The findings from the study appear to indicate that there may exist contextual differences in the decisions to cross-list, consequently generalizations may not suffice.
\end{abstract}

Keywords: cross-listing, bonding, growth opportunities, investor recognition analyst coverage

\section{Introduction}

The motivation for cross-listing has attracted interest from many scholars who have attributed the phenomena to a number of reasons, and various studies provide different levels of empirical evidence in support of these reasons. Merton (1987) put forth the visibility/investor recognition hypothesis to explain the motivation for cross-listing. According this hypothesis, increased visibility and investor recognition occasioned by cross-listing increases investor base resulting in lower expected returns and hence increased firm value. This view is supported by empirical studies by Mitoo (1992) Fanto and Karmel (1997) Bancel and Mitoo (2001), Baker et al., (2002), Lang et al., (2003), King and Segal (2006). Baker (1992) further argued that increased visibility can boost corporate marketing efforts by broadening product identification among investors and consumers in the host country.

Domowitz et al., (1998) suggested the analyst coverage hypothesis, which predicts that an increase in trading activity resulting from cross-listing induces entry of analysts. This reduces base level volatility because opening prices are more informative leading to positive valuation effects. This is postulated to enhance price discovery. Empirical findings by Brockman and Chung (1999) support this view. Ahimud and Mendelson (1998) theorize that narrower spreads following cross-listing generate improved liquidity which lowers the cost of capital and increases share value. This position is supported by empirical findings by Peroti and Cordfunke (1997), Bris et al., (2007), Eun and Sabherwal (2003) and Bris et al., (2011). Stulz (1999) believes that cross-listing provides financial gains by enabling firms get more money from investors when they offer their stocks to the public. According to Karolyi (1998) cross-listing can also improve a firm's ability to effect structural transactions abroad such as stock swaps acquisitions and other tender offers.

Doidge et al., (2004) on the other hand advanced the growth opportunities hypothesis, which posits that the main incentive for cross-listing is the desire to exploit growth opportunities. According to the hypothesis, firms with higher growth prospects are more likely to cross-list. This hypothesis postulates that high growth firms are likely to have positive valuation affects both pre and post cross-listing. This view is supported by empirical studied by Pagano et al., (2002), Tolmunen and Torstila (2005) and Sarkissian and Schill (2011).

Coffee (1999 (Note 1) 2002) advanced the bonding hypothesis to explain the reason behind the decision of firms 
to cross-list. He postulates that foreign firms from jurisdictions with potentially weaker investor (Note 2) protection can increase their valuation by bonding themselves to the US securities regime through cross-listing. Bonding hypothesis is supported by empirical studies by Facio et al., (2001), Reese and Weisbach (2002) and (2004), Doidge et al., (2004), (2005), King and Segal (2004) and Dyke and Zingales (2004). Licht (2003) has however put forth divergent theoretical views on the bonding hypothesis and argued that the bonding hypothesis is completely unfounded, and contends that instead of bonding most issuers of foreign securities may actually be avoiding better governance. Litvak $(2007 ; 2008)$ finds a positive correlation between the cross-listing premia of cross-listed firms subject to U.S. and the indices of National Association of Securities Dealers Automated Quotations (NASDAQ) and of the Standard and Poor-500 and proposes the mimicry hypothesis to explain the observed correlation. The hypothesis posits that, the more a foreign firm trades on a host country, the more it is treated as a host country firm by the investors and the more its premium tracks the stock prices of the host country's firms.

All the reasons advanced have been interpreted from analysis of secondary data (accounting and financial information). None of the studies cited have analyzed the motivation for cross-listing from a survey of managerial reasons influencing the decision to cross-list. The purpose of this study was to investigate the key reasons that influenced the decision by the firm management to cross-list. A majority of cross-listings have been from relatively lesser developed markets to more developed markets with stricter regulations, as a consequence, most of the studies on cross-listing have tended to study the cross-listing behavior from this stand point. One of the most conspicuous resultant hypothesis for the cross-listing behavior has been the bonding hypothesis. The argument of this study is that the explanation for cross-listings in East Africa cannot be viewed from the stand point of the bonding hypothesis. Specifically the study postulated that the cross-listings in the East African region cannot be motivated by the desire for legal bonding; instead the study hypothesized that the desire to exploit growth opportunities was a more plausible reason.

\section{Method}

The study employed a descriptive research design because the purpose of the study was to explore and describe observed phenomena. There were 58 firms listed in the NSE at the time this study was carried out. The population of the study however consisted of 15 firms; seven firms that had cross-listed in either or all of East African Exchanges of Uganda, Tanzania and Rwanda, plus another eight firms with pending applications for cross-listing.

\subsection{Materials}

To determine the key reasons for the motivation for the cross-listings in the East African region, a questionnaire with a list of 22 potential reasons (Likert type) for cross-listing was administered to the CEOs/CFOs of the fifteen firms. The study conducted factor analysis to identify the key reasons for the cross-listing in the East African region. Factor analysis is primarily used for data reduction or structure detection. Since the focus of the study was on data reduction, the principal components method of extraction was used. This method begins by finding a linear combination of variables (a component/factor) (Note 3) that accounts for as much variation in the original variables as possible. It then finds another component that accounts for as much of the remaining variation as possible and is uncorrelated with the previous component, continuing in this way until there are as many components as original variables. Usually, a few components will account for most of the variation, and these components can be used to replace the original variables.

\section{Results}

As a precondition to using factor analysis, the study conducted the measure of sampling adequacy (MSA) test, which has become the standard test procedure for the factor analysis, the test statistics are reported in Table 1. Kaiser (1970) recommends a cut off of 0.50 . Given that the sample MSA test score was 0.678 , the factor analysis was found to be justifiable.

Table 1. Kaiser-meyer-olkin and Bartlett's test

\begin{tabular}{ccc}
\hline Kaiser-Meyer-Olkin Measure of Sampling Adequacy. & 0.678 \\
\hline Bartlett's Test of Sphericity & Approx. Chi-Square & 21.735 \\
df & 14 \\
Sig. & 0.000 \\
\hline
\end{tabular}


The Scree plot presented in Figure 1 from the factor analysis output facilitates the determination of the number of factors to extract. Using the elbow rule, four components /factors (those above the asterix on the scree plot) were delineated for interpretation.

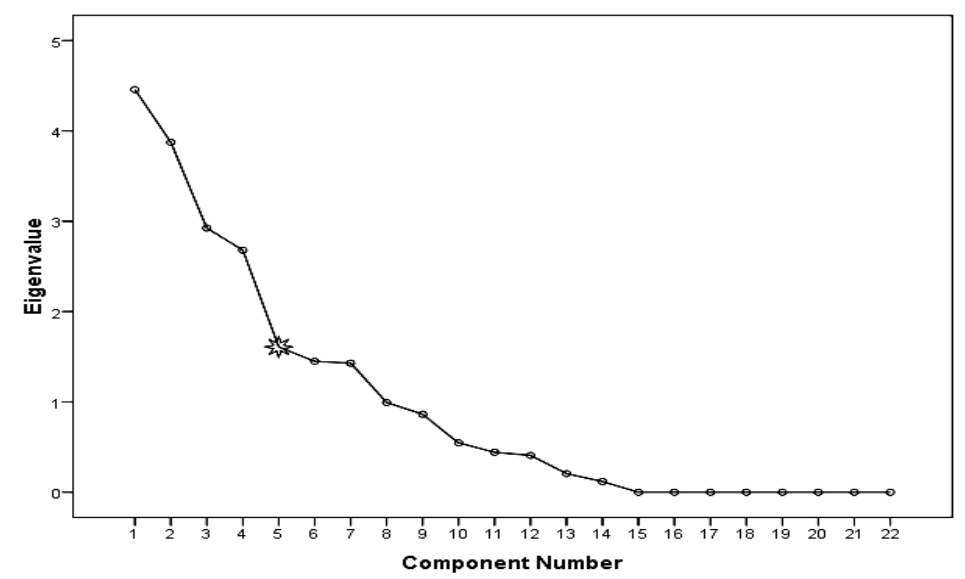

Figure 1. Scree plot

Table 2 presents the variation explained by the four extracted components /factors. The four components /factors combined explain $63.343 \%$ of the total variation. This means that they account for almost two thirds of the latent meanings in the original 22 variables.

Table 2. Total variance explained

\begin{tabular}{|c|c|c|c|c|c|c|c|c|c|}
\hline \multirow[b]{2}{*}{ Componen } & \multirow[b]{2}{*}{ t Total } & \multicolumn{2}{|c|}{ Initial Eigen values } & \multicolumn{3}{|c|}{$\begin{array}{l}\text { Extraction Sums of Squared } \\
\text { Loadings }\end{array}$} & \multicolumn{3}{|c|}{$\begin{array}{c}\text { Rotation Sums of Squared } \\
\text { Loadings }\end{array}$} \\
\hline & & $\begin{array}{c}\% \text { of } \\
\text { Variance }\end{array}$ & Cumulative $\%$ & Total & $\begin{array}{c}\% \text { of } \\
\text { Variance }\end{array}$ & Cumulative \% & Total & $\begin{array}{c}\% \text { of } \\
\text { Variance }\end{array}$ & Cumulative $\%$ \\
\hline 1 & 4.458 & 20.263 & 20.263 & 4.458 & 20.263 & 20.263 & 4.324 & 19.655 & 19.655 \\
\hline 2 & 3.873 & 17.605 & 37.868 & 3.873 & 17.605 & 37.868 & 3.527 & 16.031 & 35.686 \\
\hline 3 & 2.925 & 13.294 & 51.162 & 2.925 & 13.294 & 51.162 & 3.126 & 14.209 & 49.894 \\
\hline 4 & 2.680 & 12.181 & 63.343 & 2.680 & 12.181 & 63.343 & 2.959 & 13.448 & 63.343 \\
\hline 5 & 1.609 & 7.314 & 70.657 & & & & & & \\
\hline 6 & 1.448 & 6.584 & 77.241 & & & & & & \\
\hline 7 & 1.430 & 6.498 & 83.740 & & & & & & \\
\hline 8 & .993 & 4.513 & 88.252 & & & & & & \\
\hline 9 & .863 & 3.923 & 92.175 & & & & & & \\
\hline 10 & .547 & 2.487 & 94.661 & & & & & & \\
\hline 11 & .442 & 2.009 & 96.671 & & & & & & \\
\hline 12 & .408 & 1.854 & 98.525 & & & & & & \\
\hline 13 & .206 & .936 & 99.461 & & & & & & \\
\hline 14 & .119 & .539 & 100.000 & & & & & & \\
\hline 15 & $*$ & $*$ & 100.000 & & & & & & \\
\hline 16 & $*$ & $*$ & 100.000 & & & & & & \\
\hline 17 & $*$ & * & 100.000 & & & & & & \\
\hline 18 & $*$ & $*$ & 100.000 & & & & & & \\
\hline 19 & $*$ & $*$ & 100.000 & & & & & & \\
\hline 20 & $*$ & $*$ & 100.000 & & & & & & \\
\hline 21 & $*$ & $*$ & 100.000 & & & & & & \\
\hline 22 & $*$ & * & 100.000 & & & & & & \\
\hline
\end{tabular}


The next step was that of discerning the meanings that are represented by the four components. This is done though picking out the variables that have the highest correlation with the factor and determining what they represent collectively. A rotated component matrix helps in this process. The study used the varimax method of rotation with Kaizer normalization. From the component rotation matrix presented in Table 3 the variables with the highest correlation with component 1 were "To increase investor base, 0.958 " and "To increase visibility, 0.867" the study inferred this to represent investor recognition. Component 2 was highly correlated with "To exploit growth opportunities, 0.876" and "To facilitate mergers and acquisitions 0.740 " the study interpreted this to represent expansion of business. Component 3 was highly correlated with "To broaden product identification, 0.723" and "To boost corporate marketing efforts, 0.846 " the two were taken to represent boosting of sales. Component 4 was highly correlated with "To reduce the cost of capital, 0.711 " and "Access to external capital, 0.777 " these were taken to represent lower cost of capital.

Table 3. Rotated component matrix

\begin{tabular}{lcccc}
\hline & \multicolumn{4}{c}{ Component } \\
\cline { 2 - 5 } Variables & 1 & 2 & 3 & 4 \\
\hline To facilitate mergers and acquisitions & .029 & .740 & -.376 & .199 \\
To facilitate better price discovery & -.129 & -.040 & -.056 & -.331 \\
To broaden product identification & .136 & -.094 & .723 & .156 \\
To reduce the cost of capital & .076 & -.332 & .425 & .711 \\
To fend off competition & .221 & -.080 & -.662 & -.028 \\
To take advantage of favorable tax laws & .340 & -.092 & .437 & -.208 \\
To improve corporate governance image & -.470 & .304 & -.115 & -.173 \\
To signal positive future prospects & .248 & -.269 & -.182 & -.380 \\
To invest excess cash flows & -.712 & -.157 & -.194 & -.143 \\
To mitigate expropriation of private benefits & .441 & .284 & .256 & -.433 \\
To take advantage of low production costs & -.337 & .341 & .412 & .116 \\
To offer better protection for investors & -.059 & .221 & -.225 & .382 \\
To increase liquidity & .341 & -.578 & -.399 & .208 \\
To increase firm visibility & .867 & -.139 & -.503 & .404 \\
To boost corporate marketing efforts & .279 & .272 & .846 & .199 \\
To reduce information asymmetries & .761 & -.308 & .152 & -.179 \\
To increase investor base & .958 & .271 & -.216 & -.093 \\
To increase the market value of the firm & .299 & -.184 & .080 & .030 \\
To support the drive for regional integration by states & -.728 & -.310 & .195 & .070 \\
Access to external capital & -.012 & .276 & .050 & .777 \\
To offer better protection for investors & .296 & .876 & .106 & .147 \\
To exploit growth opportunities & & .208 & -.011 & .322 \\
\hline
\end{tabular}

Extraction Method: Principal Component Analysis, Rotation Method: Varimax with Kaiser Normalization

\section{Discussions}

The key reasons behind the decision to cross-list from a managerial perspective appeared to be to increase investor recognition. This was in line with Merton (1987) investor recognition hypothesis. The other reason coming out of the survey was the desire for expansion, which lends credence to Doidge et al., (2004) growth opportunities hypothesis. In line with this hypothesis cross-listing in East Africa exchanges by NSE listed firms appeared to be 
to facilitate mergers and acquisitions in their drive for expansion. Boosting of sales also featured as one of the key reasons for cross-listing by NSE listed firms and this reason appear to support the view by baker (1992). The last key reason extracted from the factor analysis was the desire to reduce the cost of capital. This reason was more in line with Ahimud and Mendelson (1998). The factor analysis did not provide evidence that legal bonding is a motivation for the cross-listing by NSE firms. The study's hypothesis that the cross-listings in East Africa were motivated by the desire to exploit growth opportunities was supported, a better term to describe the exploitation of growth opportunities was however given as expansion of business.

\section{Conclusion}

The purpose of this study was to investigate the key reasons behind the decision by the firm management to cross-list. The study conjectured that, for firms that have cross-listed in East Africa, the decision to cross-list is not driven by the desire to protect investors and hypothesized that the decision to cross-list is driven by the desire to exploit growth opportunities. The study conducted factor analysis which identified investor recognition, expansion of business, boosting of sales and desire to lower the cost of capital as key reasons motivating cross-listings in the East African region. The findings from the study appear to indicate that there may be contextual differences in the decisions to cross-list. The decisions to cross-list in more developed markets may not be the same reasons informing decisions to cross-list in similar or lesser developed markets. With this in mind more extensive surveys of managerial motivations may be conducted with a view to determining the extent to which their objectives are met by the action of cross-listing given the costs involved.

\section{References}

Amihud, Y., \& Mendelson, H. (1988). Liquidity and asset prices: Financial management implications. Financial Management, 5, 1-7.

Baker, K. (1992). Why U.S. Companies list on the London, Frankfurt, and Tokyo stock exchanges. Journal of International Secondary Markets, 6, 219-221.

Baker, K., John, N., \& Weaver, G. (2002). International cross-listing and visibility. Journal of Financial and Quantitative Analysis, 37(3), 495-521. http://dx.doi.org/10.2307/3594990

Bancel, F., \& Mittoo, R. (2001). European managerial perceptions of the net benefits of foreign stock listings. European Financial Management, 7(2), 213-36. http://dx.doi.org/10.1111/1468-036X.00153

Bris, A., Cantale, S., \& Nishiotis, G. (2007). A breakdown of the valuation effects of international cross-listing. European Journal of Management, 13(3), 298-330.

Bris, A., Cantale, S., Hrnjic, E., \& Nishiotis, G. (2011). The Value of Information in Cross-Listing. Journal of Corporate Finance, In Press.

Brockman P., \& Chung D. (1999). Cross-listing and firm liquidity on the stock exchange of Hong Kong. Managerial Fiannce, 25(1), 64-88. http://dx.doi.org/10.1108/03074359910765867

Coffee, C. (1999). The future as history: The prospects for global convergence in corporate governance and its implications. Northwestern University Law Review, 93(3), 641-708.

Doidge, C. (2004). U.S. cross-listings and the private benefits of control: Evidence from dual class Firms. Journal of Financial Economics, 72, 519-553. http://dx.doi.org/10.1016/S0304-405X(03)00208-3

Doidge, C., Karolyi, A., \& Stulz, R. (2004). Why are foreign firms listed in the U.S. worth more? Journal of Financial Economics, 71(2), 205-538. http://dx.doi.org/10.1016/S0304-405X(03)00183-1

Domowitz, I., Glen, J., \& Madhavan, A. (1998). International cross-listing and order flow migration: Evidence from an emerging market. Journal of Finance, 53, 2001-2027. http://dx.doi.org/10.1111/0022-1082.00081

Dyck, A., \& Zingales, L. (2004). Private benefits of control: an international comparison. Journal of Finance, 537-600. http://dx.doi.org/10.1111/j.1540-6261.2004.00642.x

Eun, C., \& Sabherwal S. (2003). Cross-border listings and price discovery: Evidence from U.S.-listed Canadian stocks. The Journal of Finance, 58(2), 549-575. http://dx.doi.org/10.1111/1540-6261.00537

Faccio, M., Lang, L., \& Young, L. (2001). Dividends and expropriation. American Economic Review, 91, 54-78. http://dx.doi.org/10.1257/aer.91.1.54

Fanto, A., \& Karmel R. (1997). A Report on the attitudes of foreign companies regarding a U.S. Listing. Stanford Journal of Law, Business and Finance, 3(1), 51-83. 
Fuerst, O. (1998). A theoretical analysis of the investor protection regulations argument for global listing of stocks. Yale School of Management. from http://51lunwen.org/UploadFile/org201101301048129607/20110130104812102.pdf

John C. Coffee Jr. (2002). Racing towards the top: The impact of cross-listings and stock market competition on international corporate governance. Columbia University Center for Law and Economic Studies Working Paper No. 205.

Jordan, C. (2006). The chameleon effect: Beyond the bonding hypothesis for cross-listed securities. Retrieved from http://ssrn.com/sol3/Delivery.cfm?abstractid=901768

Kaiser, H. (1970). A second generation little jiffy. Psychometrika, Springer, 35(4), 401-415. http://dx.doi.org/10.1007/BF02291817

Karolyi, A. (1998). Why do companies list shares abroad? A survey of the evidence and its managerial implications. Financial Markets, Institutions and Instruments, 7(1), 1-60. http://dx.doi.org/10.1111/1468-0416.00018

Kathuri J, Pals D. (1993). Introduction to Educational Research. Njoro: Egerton University.

King, M., \& Segal, D. (2004). International cross-listing and the bonding hypothesis. Bank of Canada working Paper No. 2004-17.

Lang, M., Lins, K., \& Miller, D. (2003). ADRs, analysts and accuracy: Does cross-listing in the United States improve a firm's information environment and increase market value? Journal of Accounting Research, 41(2), 317-345. http://dx.doi.org/10.1111/1475-679X.00106

Licht, A. (2003). Cross-listing and corporate governance: Bonding or avoiding? Chicago Journal of International Law, 4(1), 144-163.

Litvak, K. (2007). Sarbanes-Oxley and the cross-listing premium. Michigan Law Review, 105(8), 1857-1898.

Litvak, K. (2008). The correlation between cross-listing premia, US stock prices, and volume of US trading: A challenge to law-based theories of cross-listing. Retrieved from http://www.nber.org/public_html/confer/2008/si2008/CL/litvak.pdf

Merton, C. (1987). A simple model of capital market equilibrium with incomplete information. Journal of Finance, $42,483-504$.

Michael R. K., \& Segal, D. (2006). The long-term effects of cross-listing, investor recognition, and ownership structure on valuation. Retrieved from http://ssrn.com/sol3/papers.cfm?abstract id $=924585$

Mittoo, R. (1992). Managerial perceptions of the net benefit of foreign listing: Canadian evidence. Journal of International Financial Management and Accounting, 4, 40-62. http://dx.doi.org/10.1111/j.1467-646X.1992.tb00021.x

Pagano, M., Röell, A., \& Zechner, J. (2002). The geography of equity listing: why do companies list abroad? Journal of Finance, 57(6), 2651-2694. http://dx.doi.org/10.1111/1540-6261.00509

Peroti, E., \& Cordfunke, E. (1997). Do foreign cross-listings increase firm value? Evidence from announcement effects of Dutch firms. Retrieved from http://dare.uva.nl/document/226

Reese, A., \& Weisbach, S. (2002). Protection of minority shareholder interests, cross-listings in the United States, and subsequent equity offerings. Journal of Financial Economics, 66, 65-104. http://dx.doi.org/10.1016/S0304-405X(02)00151-4

Reese, A., \& Weisbach, S. (2011). The nature of the foreign listing premium: A cross-country examination. Munich Personal RePEc Archive, Paper No. 28653. Retrieved from http://mpra.ub.uni-muenchen.de/28653

Stulz, R. (1999). Globalization, corporate finance, and the cost of capital. Journal Applied Corporate Finance, 8 , $1-12$.

Tolmunen, P., \& Torstila, S. (2005). Cross-listings and M \& A activity: Transatlantic evidence. Financial Management, 34(1), 123-142. http://dx.doi.org/10.1111/j.1755-053X.2005.tb00094.x

\section{Notes}

Note 1. Thought extant literature attributed bonding hypothesis to Coffee (1999), Fuerst (1998) presented a formal model analyzing the investor protection regulations argument for cross listing which was the basis of the 
bonding hypothesis. The model lent credence to the bonding hypothesis.

Note 2. Though not offering an alternative explanation for cross-listings, Jordan (2006) regards the bonding hypothesis as unfounded. She questions the main assumption of the bonding hypothesis that the American legal system is superior to others such as the UK or Canada in the protection of shareholders. She regards this assertion "the classic blunder of the amateur comparativist, confounding difference with deficiency".

Note 3. The words component and factor are used interchangeably. 